\title{
Effects of Bank Branch Competition on Rural Firm Entry and Exit: Evidence from Hokkaido, Japan
}

\author{
Kozo Harimaya ${ }^{*}$, Yasufumi Ozaki ${ }^{2}$ \\ ${ }^{1}$ College of Business Administration, Ritsumeikan University, Ibaraki, Japan \\ ${ }^{2}$ Kushiro Public University of Economics, Kushiro, Japan \\ Email: ^harimaya@fc.ritsumei.ac.jp
}

How to cite this paper: Harimaya, K. and Ozaki, Y. (2018) Effects of Bank Branch Competition on Rural Firm Entry and Exit: Evidence from Hokkaido, Japan. Theoretical Economics Letters, 8, 390-404. https://doi.org/10.4236/tel.2018.83028

Received: December 22, 2017

Accepted: February 9, 2018

Published: February 12, 2018

Copyright (c) 2018 by authors and Scientific Research Publishing Inc. This work is licensed under the Creative Commons Attribution International License (CC BY 4.0).

http://creativecommons.org/licenses/by/4.0/

\section{(c) (i) Open Access}

\begin{abstract}
This paper investigates the effects of bank branch competition on rural firm entry and exit in Hokkaido, the largest and northernmost prefecture in Japan. Using a panel dataset of 188 municipalities, we run a two-stage least squares regression to examine whether banking competition affects firm entry and exit, respectively. Although the empirical evidence does not strongly support the notion of simultaneously linked firm entry and exit, banking competition has a negative effect on firm exit rates. Furthermore, consistent results are obtained when running a seemingly unrelated regression. Our findings suggest that fierce competition among banks does not contribute to firm survival and region-based relationship banking in less competitive areas can deter firm exit.
\end{abstract}

\section{Keywords}

Japanese Regional Bank, Bank Branch, Relationship Banking, Firm Entry and Exit

\section{Introduction}

Small and medium-sized enterprises (SMEs) suffer from information asymmetry in financing constraints due to of credible financial data (Leland and Pyle [1]). The private information generated by the strong market power of lenders yields hold-up problems and extracting rents from firms (Sharpe [2]; Rajan [3]). Particularly, SMEs in rural areas face severe financing constraints due to their limited access to alternative financing providers. However, the direction of the relationship between banking competition and credit availability is mixed. While 
some empirical studies support the traditional market power view that less competitive banking markets are associated with a lower credit availability and higher credit prices (Hannan [4]; Black and Strahan [5]; Beck et al. [6]; Agostino and Trivieri [7]; Chong et al. [8]), other studies find the reverse link in which a higher concentration is associated with greater credit availability (Petersen and Rajan [9] [10]; Zarutskie [11]; Fischer [12]). Moreover, Jayaratne and Wolken [13] and Berger et al. [14] do not find any association between concentration and the dependence on trade credit.

In Japan, the overall business environment of SMEs has been facing difficulties following the collapse of the bubble economy in the early 1990s and the subsequent prolonged economic slump. Moreover, since the economic disparities between regions have been gradually increasing, the rural financial environment is possibly worsening. While the Tokyo Metropolitan area has an excess concentration of population and industry, other regions have obviously been left out by the middle of the 2000s. A region's economic condition may be related to the financing constraints borrowers face. A typical Japanese region is the Hokkaido prefecture, the northernmost island, with an area of $83424.22 \mathrm{~km}^{2}$, comprising $22 \%$ of the country's total land area. ${ }^{1}$ In other words, it is roughly the same size as Austria and twice that of the Netherlands or Switzerland.

Hokkaido witnessed the bankruptcy of its largest commercial bank, the Hokkaido Takushoku Bank (hereafter, Takugin) in 1997. This collapse was the first case of a "city bank" (major commercial bank with headquarters in major cities) failure in post-war Japan. ${ }^{2}$ Takugin was a "Special Bank", formed in the late 19th century to promote capitalism in Hokkaido. At that time, Hokkaido was a frontier land. Although Takugin was privatised after World War II and opened new branches in the big mainland cities such as Tokyo and Osaka, it held remarkable shares on the deposit and loan markets of Hokkaido. Therefore, its bankruptcy had a significant effect on Hokkaido, especially on borrowers. Indeed, Yamori and Murakami [15] examined the effect of Takugin's bankruptcy on its customers using the event study approach, and concluded that it adversely affected borrowers' market value. Following the bank's collapse, its Hokkaido operations were absorbed by Hokuyo Bank, a regional bank in Hokkaido. Although most of Takugin's branches continued their operation for a while, Hokuyo Bank soon initiated a scrap-and-build for branch offices. As a result, the total number of Hokuyo bank branches decreased from 231 at the end of FY 1998 to 175 by 2014.

The main purpose of this paper is to examine whether the competition between financial institutions affects firm creation and survival in Hokkaido. The reasons for selecting Hokkaido are as follows. First, Hokkaido has suffered nu-

\footnotetext{
${ }^{1}$ Japan is divided into 47 administrative divisions, Hokkaido being by far the largest and having the lowest population density at 65 persons per $\mathrm{km}^{2}$ as of the end of FY 2014. Hokkaido accounted for $3.6 \%$ of Japan's total GDP in 2014.

${ }^{2}$ In Japan, the large commercial banks that provide banking services nationwide and internationally are called "city banks" (Togin in Japanese). They have their headquarters in major cities, and branches located throughout the country. There were 13 city banks as of March 1990, while presently, there are three megabank groups following a wave of consolidations.
} 
merous serious economic problems due to the abovementioned unprecedented large commercial bank failure. As such, the number of bankruptcies increased and the unemployment rate rose. ${ }^{3}$ Therefore, SME financing constraints were severe. Second, the degree of competition in rural banking markets gradually changed due to the restructuring of the bank branch network. Hokuyo Bank, which inherited Takugin's branches, merged with Sapporo Bank in 2008. Similarly to the previous Takugin branches, Hokuyo Bank streamlined the overlapping branch offices after the merger. Finally, since Hokkaido is an island, only the local financial institutions can be considered when investigating the measures of competitiveness on the local financial market.

Moreover, the downward trend in the number of businesses continued: the number of firm exits exceeded the number of new entrants over the past two decades. Therefore, the possible simultaneous relationship between firm entry and exit generally assumed in previous research (Dunne et al. [16]; Geroski [17]) appears to be insignificant. Consequently, it is conceivable that an important issue for regional financial institutions having numerous branches in rural areas is to control the number of exiting establishments: a decline in firm creation may also reduce the loan volume of financial institutions. Indeed, while not restricted to Hokkaido, the loan-to-deposit ratio of regional financial institutions has been slightly declining. ${ }^{4}$

The main contribution of this paper is the empirical identification of the impact of competition between financial institutions on firm creation and survival in local regions suffering from severe economic difficulties due to commercial bank failures. Even though this paper investigates the issue at one of Japan's economically distressed regions, the findings of this paper will provide valuable input to other similar regions worldwide.

The remainder of this paper is structured as follows. Sections 2 reviews the relevant literature. Section 3 explains the empirical methodology and Section 4 discusses the data. Section 5 presents the empirical results and Section 6 the main conclusions.

\section{Literature Review}

Regarding the effect of bank competition on firm entry, Cetorelli and Strahan [18] analyse the impact of bank concentration on small US firms, and find that potential entrants face greater difficulty gaining access to credit if they operate in a more concentrated bank market. Rogers [19] examines the impact of bank market structure for US states, and shows that a widespread presence of bank branches per capita and more small banks are linked with increased entrepreneurship. Moreover, there are studies showing that new business incorporations and income growth followed the US branching deregulation in the mid-1990s

${ }^{3}$ Hokkaido's unemployment rate increased from $3.7 \%$ in 1997 to $6.5 \%$ in 2003 . During the same period, the rate increased from $2.5 \%$ to $5.2 \%$ for the entire country.

${ }^{4}$ The loan-to-deposit ratio of banks (excluding cooperative institutions) fell steadily from $78.0 \%$ at the end of FY 2000 to $64.1 \%$ by 2015 . 
(Black and Strahan [5]; Jayaratne and Strahan [20]; Kerr and Nanda [21]; Rice and Strahan [22]). Using industry-level data for 41 countries, Cetorelli and Gambera [23] find that banking concentration has a negative effect on firm growth, although the effect was found to be heterogeneous across industries. These empirical findings support traditional industrial organization theory, which considers the exercise of market power problematic.

On the other hand, there are studies that analyse the effect of the relationship lending on firm financing constraints, and find a negative competition effect. Boot [24] argues that prior lender-borrower relationships help reduce the information asymmetry between banks and firms. From the viewpoint of credit availability, Degryse and Van Cayseele [25] and Chakraborty and Hu [26] also show that a good lending relationship helps reduce the amount of assets required as securities for loan provision. In the context of relationship banking, "soft" information is the most valuable type of data banks collect and use. Regarding the organizational structure of banks, Berger and Udell [27] suggest that a small "community banking" environment is desirable for small business financing. Scott [28] also provides evidence that small banks are more capable than large ones of producing "soft" information. Moreover, regarding the effect on firm entry, Bonaccorsi di Patti and Dell'Ariccia [29], using industry-data on Italian firms, find that the rate of firm creation is higher in provinces with a more concentrated banking sector but too much concentration becomes harmful. These results are consistent with those of Peterson and Rajan [10], who show that as the concentration of the banking sector increases, the financial constraints of firms decrease.

Compared to firm creation, limited studies investigate the impact of interbank competition on firm survival. Therefore, this paper will provide new evidence for these studies. Regarding the determinants of SME bankruptcies, Shimizu [30] finds that smaller banks reduce the bankruptcy ratio of small firms and increase the recovery rate from financial distress based on Japanese data. Berger et al. [31] also find that a greater market share of small banks helps small and opaque US start-up firms receive loans, although the effect declines sharply during financial crises. These results are consistent with the above-mentioned studies that highlight the organizational advantages of small banks. ${ }^{5}$ In Hokkaido, there are some local municipalities where only one branch of a cooperative financial institution exists. If these types of banks operate similarly in these local regions, higher concentration might be associated with a higher probability of firm survival.

Regarding the interrelationship between firm entry and exit, the industrial organization literature generally shows a positive correlation in all industries (Shapiro and Khemani [35]; Dunne and Roberts [36]; Evans and Siegfried [37]). Some studies focus on firm age and size as determinants of this relationship

${ }^{5}$ Regarding the advantages of small banks, numerous empirical studies show that small banks are more willing to deliver bank loans to SMEs than large banks (Berger et al. [32]; Berger and Udell [33]; Keeton [34]). 
(Bernard and Jensen [38]; Dunne et al. [16]; Philips and Kirchhoff [39]). Indeed, one may assume that regions with more firm entries can expect more firm exits, because younger firms are more likely to become bankrupt. In addition to the years in business, firm size is also associated with the probability of bankruptcy. ${ }^{6}$ Larger firms often diversify and typically have stable cash flows, their probability of bankruptcy being lower than for smaller firms. However, these studies do not sufficiently account for the effect of bank competition as a determinant of the interrelationship between firm entry and exit.

\section{Empirical Methodology}

This paper considers the effect of interbank competition, and examines the issue of a possible simultaneous relationship between firm entry and exit. The system of two linear equations under consideration is expressed as follows:

$$
\begin{gathered}
\operatorname{ENTRY~}_{i, t}=\alpha_{0}+\alpha_{1} \operatorname{EXIT}_{i, t}+\alpha_{k} X_{m, t-1}+u_{i, t}, \\
\operatorname{EXIT}_{i, t}=\beta_{0}+\beta_{1} \operatorname{ENTRY~}_{i, t}+\beta_{k} X_{n, t-1}+e_{i, t},
\end{gathered}
$$

where $E N T R Y_{i, t}$ and $E X I T_{i, t}$ represent the entry and exit rates of firms for the $i$-th area in the $t$-th period, respectively; $X_{m, t-1}$ and $X_{n, t-1}$ the vectors of exogenous determinants, including degree of bank competition in each municipality in the $t-$ 1-th period; $\alpha$ and $\beta$ the parameters to be estimated; and $u_{i, t}$ and $e_{i, t}$ the error terms.

We apply a two-stage least squares (2SLS) for panel data, estimating Equations ((1) and (2)) separately to investigate the endogeneity of firm entry and exit, respectively. Thus, as well as ad hoc standards in panel data analysis, the unobserved error terms in Equations ((1) and (2)), $u_{i, t}$ and $e_{i, p}$ consist of two components: one representing the time invariant, unobservable characteristics of each area, and the other representing the genuine error term that varies across areas and time. The former component is assumed to be uncorrelated with the variables in $X_{m, t-1}$ and $X_{n, t-1}$ because we employ a method based on random effects model. While some studies employ a simultaneous equation approach, no clear evidence of underlying processes of endogeneity can be found for firm entry or exit (Anagnostaki and Louri [40]; Love [41]; Fotopoulos and Spence [42]). Regarding the determinants of firm entry, a common hypothesis that firm creation is caused by firm termination is supported by previous studies (Austin and Rosenbaum [43]; Evans and Siegfried [37]). Indeed, new firms may choose to locate where the firm exit rate is high, as physical assets could be obtained less expensively and reused easily there.

Moreover, to confirm the robustness of the results, a seemingly unrelated regression (SUR) model is also applied. Shapiro and Khemani [35] were the first to investigate the interdependence between firm entry and exit using the SUR method. Regarding the consideration for the simultaneity of entry and exit, Carree and Thurik [44] and Manjón-Antolín [45] use SUR and three-stage least ${ }^{6}$ Bernard and Jensen [38] find that age, as well as size, significantly affect the probability of plant shutdown for US multinational manufacturing firms. 
squares (3SLS), and compare the results. Both estimation techniques are consistent under the null hypothesis of exogeneity. However, Carree and Thurik [44] report that SUR is more efficient because it is not consistent under the alternative hypothesis of endogeneity, while 3SLS is. Moreover, 3SLS is more sensitive and vulnerable to misspecifications, and does not allow for the clustering of standard errors.

\section{Data}

Since consecutive annual data on the number of firms are not available, three datasets for the following periods are used: 2009-2011, 2011-2014, and 20142016. These data are drawn from the Economic Census for Business Frame of Japan, published by the Management and Coordination Agency. ${ }^{7}$ Since each dataset has the same number of observations, we consider the use of a balanced panel. To use the annual average entry and exit rates, the figures above are divided by the number of months in the survey period and multiplied by 12 . The data include only private establishments, excluding public enterprises. Since the number of firms having branches without head offices would be small, especially in rural areas, the number of firms is similar to the number of establishments. However, we further examine excluding branches from the dataset.

Among the independent variables, we consider the measure of competition in the banking sector as a key factor that affects both firm entry and exit rates. In this paper, the Herfindahl-Hirschman index (HHI), based on number of branches of financial institutions at the municipal level, is taken as the proxy for the competition level. ${ }^{8}$ However, this does not provide the actual competitiveness that captures the differences between the sizes of financial institutions. For instance, when a regional bank and a small local cooperative financial institution have one branch respectively in a rural municipality, the HHI would be 5000 as per the standard definition, because each institution has a $50 \%$ branch-based market share. To make the competition measure more realistic, the assetweighted branch shares are computed as follows. First, the share of total assets among the financial institutions in Hokkaido is multiplied by the number of branches in each municipality. Second, the HHI is generated by summing up the squared market shares obtained above. ${ }^{9}$ For calculating the HHI, the branches of cooperative financial institutions are considered along with those of the regional banks, because the former have a non-negligible presence in Hokkaido. Particularly, credit associations (Shinkin bank), representative cooperative financial institutions, have a dominant presence in Hokkaido. ${ }^{10}$ However, the mega banks'

\footnotetext{
${ }^{7}$ Since the data collection process has been changed after the 2009 Economic Census for Business Frame, the previous census figures are not continuous. Thus, although it is desirable to use a panel data over a long-time period, available data is unfortunately limited.

${ }^{8}$ While it is more appropriate to use an index based on branch-wise loan amounts, such data are not available for all financial institutions in Japan.

${ }^{9}$ When two banks have one branch respectively, if the total assets of the larger bank are nine times greater than those of the smaller bank, the modified HHI measure changes to 8200 .

${ }^{10} \mathrm{As}$ of FY 2014, credit associations held more than $20 \%$ of the loans in Hokkaido and about $10 \%$ in the entire country.
} 
branches are excluded, because they are very few and most concentrated in certain areas of Sapporo, the capital of Hokkaido prefecture. To adjust the unit value with other variables, we calculate the HHI using proportions rather than percentages. Therefore, the highest possible HHI is 1 , reflecting the complete absence of competition. Furthermore, as a determinant of both firm entry and exit rates, we define a municipality dummy variable (DMNBR) that takes the value 1 if there are no bank branches. ${ }^{11}$

Moreover, we consider several other variables that exclusively affect the entry or exit rates of firms. For the entry equation, the rate of population growth (RPG), the privately-owned establishments ratio (POER), and the share of labour force engaged in tertiary industries (SLTI) are used. The former two variables are assumed to proxy the magnitude of the changing job creation source and the liveliness of entrepreneurship, respectively, hence having positive effects on the firm entry rate. ${ }^{12}$ Since the tertiary sector consists of a range of service activities, it is relatively easy to create new firms from the viewpoint of initial cost. Additionally, the accumulation of a closely-connected network of related industries may foster new entrants. Therefore, SLTI is considered to boost the firm entry rate.

For the exit equation, the rate of change of taxable income (RCTI), unemployment rate (UER), and the old dependency ratio (OLDR) (i.e., the proportion of those aged 65 or over in the total population) are used. RCTI captures the business climate in each municipality, and may hence have a negative effect on the firm exit rate. Since a higher unemployment rate and a lower labour force participation rate indicate poor business conditions, UER and OLDR are considered positive determinants of the firm exit rate.

To avoid the simultaneous bias for estimated coefficients, these exogenous variables are timed prior to the dependent ones. For instance, the HHI at the end of FY 2008 is a factor for firm entry and exit rates for 2009-2011. The other variables are also based on the values for the preceding fiscal year. RPG and RCTI are the averages for the three years preceding the firm entry and exit rate periods. The data on the number of financial institutions' branches are retrieved from the "Directory on Japanese Finance" CD-ROMs, edited by the Japan Financial News Co., Ltd. Further, total asset data of individual banks, credit associations, and credit cooperatives are obtained from the "Analysis of Financial Statements of All Banks", edited by the Japanese Bankers Association, and the "Financial Statements of All Credit Associations" and "Financial Statements of All Credit Cooperatives", both edited by the Consultant of Financial Books Co.,

\footnotetext{
${ }^{11}$ There were six municipalities where there are no bank branches at the end of FY 2014.

${ }^{12}$ The most well-known theory of population is the Malthusian theory. However, there are many views and schools of thought regarding the relationship between population growth and economic development: either a negative, positive, or neutral relationship. The effect of population growth on new firm creation is also controversial. Guesnier [46] and Armington and Acs [47] find a significant and positive impact, whereas Audretsch and Frisch [48] and Garofoli [49] find no significant relationship. Moreover, Love [41] considers the extent of owner occupation across counties as a proxy for the availability of housing collaterals.
} 
Ltd. The municipal data, such as population, are taken from the "Financial Resources of a Nation", edited by Asahi Shimbun. Table 1 presents the basic statistics for the analysed variables. ${ }^{13}$ As the ENTRY and EXIT rows of the table show, the exit rate exceeds the entry one over the sample period, on average.

\section{Results}

\subsection{SLS Estimation Results}

Table 2 reports the 2 SLS estimation results using three datasets: full sample (Case 1), excluding branch offices (Case 2), and excluding branches and capital above

Table 1. Descriptive statistics.

\begin{tabular}{|c|c|c|c|c|c|}
\hline & Variables & Mean & Std. dev. & Min & $\operatorname{Max}$ \\
\hline$E N T R Y$ & Firm entry rates & 0.0296 & 0.0203 & 0.0024 & 0.1603 \\
\hline EXIT & Firm exit rates & 0.0535 & 0.0143 & 0.0051 & 0.1110 \\
\hline$H H I$ & Herfindahl-Hirschman index & 0.7845 & 0.2669 & 0.0000 & 1.0000 \\
\hline POER & Privately-owned establishments ratio & 0.4076 & 0.0767 & 0.1635 & 0.6183 \\
\hline$R P G$ & Rate of population growth & -0.0122 & 0.0096 & -0.0506 & 0.0287 \\
\hline$S L T I$ & Share of the labour force in tertiary industries & 0.4549 & 0.2062 & 0.0590 & 0.8293 \\
\hline$R C T I$ & Rate of change of taxable income & -0.0206 & 0.0280 & -0.1452 & 0.1018 \\
\hline$U E R$ & Unemployment rate & 0.0536 & 0.0271 & 0.0130 & 0.2940 \\
\hline$O L D R$ & Proportion aged 65 or over among the total population & 0.2889 & 0.0570 & 0.1481 & 0.4440 \\
\hline & Number of observations & \multicolumn{4}{|c|}{564} \\
\hline
\end{tabular}

Note: Numbers are expressed as decimals, not percentages.

Table 2. Determinants of firm entry and exit rates (2SLS).

\begin{tabular}{|c|c|c|c|c|c|c|c|c|c|c|c|c|}
\hline & \multicolumn{4}{|c|}{ Case 1} & \multicolumn{4}{|c|}{ Case 2} & \multicolumn{4}{|c|}{ Case 3} \\
\hline & \multicolumn{2}{|c|}{ Entry } & \multicolumn{2}{|c|}{ Exit } & \multicolumn{2}{|c|}{ Entry } & \multicolumn{2}{|c|}{ Exit } & \multicolumn{2}{|c|}{ Entry } & \multicolumn{2}{|c|}{ Exit } \\
\hline & Coef. & Std. err. & Coef. & Std. err. & Coef. & Std. err. & Coef. & Std. err. & Coef. & Std. err. & Coef. & Std. err. \\
\hline Constant & 0.0205 & 0.0167 & $0.0432^{\star * *}$ & 0.0045 & $0.0289^{* *}$ & 0.0141 & $0.0254^{* * *}$ & 0.0092 & $0.0335^{\star *}$ & 0.0138 & $0.0261^{* *}$ & 0.0105 \\
\hline EXIT & $0.4038^{*}$ & 0.2439 & & & 0.0409 & 0.2105 & & & 0.0376 & 0.2042 & & \\
\hline ENTRY & & & $0.2238^{* * *}$ & 0.0838 & & & $0.6399^{* *}$ & 0.2975 & & & $0.6336^{*}$ & 0.3531 \\
\hline$H H I$ & 0.0036 & 0.0052 & $-0.0090^{* * *}$ & 0.0030 & 0.0015 & 0.0060 & $-0.0126^{* *}$ & 0.0051 & 0.0003 & 0.0058 & $-0.0127^{\star * *}$ & 0.0048 \\
\hline$D M N B R$ & 0.0093 & 0.0063 & $-0.0083^{* *}$ & 0.0042 & 0.0035 & 0.0076 & $-0.0148^{* *}$ & 0.0072 & 0.0031 & 0.0071 & $-0.0144^{* *}$ & 0.0069 \\
\hline POER & $-0.0529^{* * *}$ & 0.0116 & & & $-0.0318^{* *}$ & 0.0133 & & & $-0.0375^{* * *}$ & 0.0126 & & \\
\hline$R P G$ & 0.1323 & 0.1014 & & & -0.0168 & 0.1160 & & & -0.0558 & 0.1088 & & \\
\hline$R C T I$ & & & -0.0154 & 0.0203 & & & -0.0215 & 0.0326 & & & -0.0085 & 0.0340 \\
\hline$U E R$ & & & $0.1174^{* * *}$ & 0.0231 & & & $0.1560^{* * *}$ & 0.0393 & & & $0.1669^{* * *}$ & 0.0363 \\
\hline$O L D R$ & & & 0.0152 & 0.0113 & & & 0.0102 & 0.0195 & & & 0.0110 & 0.0199 \\
\hline$R^{2}$ & 0.1836 & & 0.1833 & & 0.0362 & & 0.0969 & & 0.0306 & & 0.0759 & \\
\hline Observations & & 564 & & & & & & & & 564 & & \\
\hline
\end{tabular}

Note: ${ }^{* *},{ }^{* *},{ }^{*}$ represent significance at the $1 \%, 5 \%$, and $10 \%$ levels, respectively.

${ }^{13}$ The mean value of unweighted HHIs, based on the number of branches, is 0.6562 . 
JPY 100 million (Case 3). Concerning 2SLS with panel data, error-component 2SLS (EC2SLS) by Baltagi [50] and generalised 2SLS (G2SLS) by Balestra and Varadharajan-Krishnakumar [51] are commonly used. According to the theoretical assumptions, EC2SLS is asymptotically efficient relative to G2SLS when it uses more instruments. Since we are concerned only with interdependence between firm entry and exit, the G2SLS method is applied.

Regarding the endogeneity of firm entry and exit in Case 1, both coefficients are positive and statistically significant. Therefore, a higher firm exit rate is positively associated with the firm entry rate, and vice versa. On the other hand, the $\mathrm{HHI}$ coefficient is negative and statistically significant only for the exit equation. This implies that reduced competition between banks can lead to lower firm exit rates. Regarding the other exogenous variable coefficients in the entry equation, POER is negative and statistically significant at the $1 \%$ level, suggesting that a higher share of privately owned establishments in a municipality leads to a lower firm entry rate; and SLTI is positive and statistically significant at the $1 \%$ level, implying that the accumulation of tertiary industries fosters new entrants. In the exit equation, only the coefficient of UER is negative and statistically significant at the $1 \%$ level. Thus, consistent with the prior common assumption, a higher unemployment rate leads to a higher firm exit rate. Although the coefficients of RCTI and OLDR also show consistent signs, both of them are statistically insignificant.

Next, consider the endogeneity results, excluding branches (Case 2). Although the coefficient of EXIT has a positive sign, it is statistically insignificant in the entry equation. However, consistent with the result for Case 1, the coefficient of ENTRY is positive and statistically significant at the $5 \%$ level in the exit equation. Therefore, the significant relationship between firm entry and exit can be observed only from entry to exit when excluding branches. The HHI coefficient is again negative and statistically significant only for the exit equation. Moreover, the estimate is smaller than for Case 1, implying that lower bank competition strongly reduces firm exit rates when excluding branches. Regarding the other exogenous variables' coefficients, POER and UER are statistically significant in the entry and exit equations, respectively. However, unlike in Case 1, SLTI becomes insignificant in the entry equation. All other variables are still insignificant.

Finally, for the endogeneity results excluding branches and large capital in Case 3, in accordance with the results in Case 2, a significant relationship can only be observed from entry to exit and the coefficient of ENTRY is similar to that for Case 2. Moreover, $\mathrm{HHI}$ is also negative and statistically significant only for the exit equation. Therefore, as the competition between banks decreases, the exit rate of smaller firms decreases as well. Regarding the other exogenous variables' coefficients, the results are similar to those for Case 2, and only POER and UER are statistically significant.

\subsection{SUR Estimation Results}

Table 3 shows the SUR estimation results for estimating the entry and exit equations 
Table 3. Determinants of firm entry and exit rates (SUR).

\begin{tabular}{|c|c|c|c|c|c|c|c|c|c|c|c|c|}
\hline & \multicolumn{4}{|c|}{ Case 1} & \multicolumn{4}{|c|}{ Case 2} & \multicolumn{4}{|c|}{ Case 3} \\
\hline & \multicolumn{2}{|c|}{ Entry } & \multicolumn{2}{|c|}{ Exit } & \multicolumn{2}{|c|}{ Entry } & \multicolumn{2}{|c|}{ Exit } & \multicolumn{2}{|c|}{ Entry } & \multicolumn{2}{|c|}{ Exit } \\
\hline & Coef. & Std. err. & Coef. & Std. err. & Coef. & Std. err. & Coef. & Std. err. & Coef. & Std. err. & Coef. & Std. err. \\
\hline Constant & 0.0021 & 0.0066 & $0.0398^{* * *}$ & 0.0034 & 0.0090 & 0.0068 & $0.0330^{* * *}$ & 0.0048 & $0.0185^{* * *}$ & 0.0065 & $0.0355^{* * *}$ & 0.0049 \\
\hline EXIT & $0.6853^{\star * *}$ & 0.0544 & & & $0.3869^{* * *}$ & 0.0430 & & & $0.2918^{* * *}$ & 0.0414 & & \\
\hline ENTRY & & & $0.3368^{* * *}$ & 0.0263 & & & $0.3526^{* * *}$ & 0.0372 & & & $0.2940^{* * *}$ & 0.0399 \\
\hline$H H I$ & $0.0074^{*}$ & 0.0038 & $-0.0090^{* * *}$ & 0.0029 & $0.0085^{\star *}$ & 0.0042 & $-0.0135^{\star * *}$ & 0.0042 & 0.0055 & 0.0040 & $-0.0127^{* * *}$ & 0.0042 \\
\hline$D M N B R$ & $0.0128^{\star *}$ & 0.0054 & $-0.0096^{* *}$ & 0.0041 & $0.0111^{*}$ & 0.0060 & $-0.0148^{\star *}$ & 0.0059 & 0.0085 & 0.0056 & $-0.0130^{* *}$ & 0.0059 \\
\hline POER & $-0.0482^{* * *}$ & 0.0109 & & & $-0.0275^{* *}$ & 0.0122 & & & $-0.0342^{* * *}$ & 0.0116 & & \\
\hline$R P G$ & $0.1575^{*}$ & 0.0936 & & & 0.0389 & 0.1040 & & & -0.0193 & 0.0992 & & \\
\hline$S L T I$ & $0.0138^{* * *}$ & 0.0038 & & & 0.0042 & 0.0042 & & & -0.0040 & 0.0040 & & \\
\hline$R C T I$ & & & -0.0230 & 0.0195 & & & -0.0291 & 0.0286 & & & -0.0208 & 0.0288 \\
\hline$U E R$ & & & $0.0995^{* * *}$ & 0.0216 & & & $0.1541^{* * *}$ & 0.0317 & & & $0.1582^{* * *}$ & 0.0319 \\
\hline$O L D R$ & & & $0.0183^{*}$ & 0.0108 & & & 0.0080 & 0.0158 & & & 0.0020 & 0.0159 \\
\hline$R^{2}$ & 0.1385 & & 0.1407 & & 0.0265 & & 0.1109 & & 0.0222 & & 0.1016 & \\
\hline Observations & & & 64 & & & & 564 & & & 56 & & \\
\hline
\end{tabular}

Note: ${ }^{* *},{ }^{* *},{ }^{*}$ represent significance at the $1 \%, 5 \%$, and $10 \%$ levels, respectively.

simultaneously. For the full sample results in Case 1, both the coefficients of EXIT and ENTRY are positive and statistically significant at the $1 \%$ level. Thus, a significant relationship between firm entry and exit can be observed in both directions. Interestingly, in contrast to the 2SLS results in Table 2, HHI becomes significant in the entry equation. Since its coefficient is positive, increased competition between banks can lead to lower firm entry rates. In accordance with the 2SLS results in Table 2, the coefficient of HHI is still negative and statistically significant at the $1 \%$ level in the exit equation. For the other exogenous variables' coefficients, the coefficient of RPG is positive and statistically significant at the $10 \%$ level in the entry equation, suggesting that new firm creation tends to increase with population growth. Moreover, the coefficient of OLDR is positive and statistically significant at the $10 \%$ level in the exit equation, indicating that a rise in the proportion of the elderly leads to an increase in firm exit rate. Similarly to the 2SLS results in Table 2, POER, SLTI, and UER are statistically significant at the $1 \%$ level.

For the subsample results of excluding branch offices in Case 2, both the coefficients of EXIT and ENTRY are still positive. Additionally, EXIT becomes statistically significant at the $1 \%$ level in the entry equation, although it is insignificant in the 2SLS results in Table 2. Therefore, the significant relationship between firm entry and exit can be again observed in both directions. Moreover, $\mathrm{HHI}$ is also statistically significant at the $5 \%$ level in the entry equation and has a 
positive value. This indicates new firm creation may benefit from lower bank competition even when excluding branch offices. On the other hand, in contrast with Case 1, the coefficients of RPG, SLTI, and OLDR are insignificant.

For the subsample results excluding branches and large capital in Case 3, consistent with the former results for Cases 1 and 2, both coefficients of EXIT and ENTRY are positive and statistically significant at the $1 \%$ level. However, while the coefficient of HHI is still negative and statistically significant in the exit equation, it becomes insignificant in the entry equation. Since the high $\mathrm{HHI}$ is concentrated in underpopulated areas and the bank branches are those of cooperative financial institutions, such small financial institutions play a more important role for the existing SMEs than new firms. The other exogenous variables' coefficients are similar to those in Case 2.

In sum, the SUR estimation results show that a significant relationship between firm entry and exit can be observed in both directions, regardless of the samples. Moreover, the results show that interbank competition has a negative effect on the firm exit rates of SMEs. Since Shinkin banks have been holding large market shares in Hokkaido, especially in rural areas, the results suggest a strong relationship between them and their borrowers. As Shinkin banks need to give at least $80 \%$ of their loans to members, it is natural for them to fund weak loans and support the needs of existing borrowers. The results also suggest that the recent promotion of region-based relationship banking in less competitive areas could deter the closing of businesses.

\section{Conclusions}

This paper shows strong evidence that interbank competition has a negative impact on the firm exit rates in Hokkaido, which is already suffering from severe economic difficulties due to unprecedented large commercial bank failures. However, there is no clear evidence that it has significant impact on the firm entry rates. These results are consistent with previous studies that show the negative effect of bank competition on firm financing constraints, and thus explain the recent prolonged rural economic stagnation. As previously mentioned, over the past two decades, the number of firms exiting the market exceeded the number of new entrants. Since the declining entry rate and aging population problems are serious in many rural areas, the conditions are thus not conducive for the creation of new firms. The results suggest severe operational environments for regional financial institutions in less competitive areas, since they are forced to support the existing local borrowers to maintain the total outstanding loans. Moreover, the results also show a weak economy due to the scrap-andbuild of establishments, because empirical evidence does not strongly support the notion of simultaneously linked firm entries and exits.

On the other hand, the findings suggest the advantages of relationship banking on less competitive markets. Since it takes considerable time to build longlasting relationships with customers, a statistically insignificant relationship be- 
tween bank competition and the firm entry rate is not surprising. Indeed, Japan's Financial Services Agency has been striving to diversify and enable SME financing from regional financial institutions not specialised in supporting the creation and opening of new businesses. Therefore, the recent promotion of region-based relationship banking can be assumed to prevent the bankruptcy of local SMEs. Furthermore, the above findings suggest the importance of bank branches in rural areas in supporting the sustainable growth of existing SMEs. However, whether such local branches contribute to the productivity growth of each financial institution and regional economy remains inconclusive. In the near future, we hope to conduct further studies of the function of a local bank branch more precisely.

\section{Acknowledgements}

We would like to thank the anonymous referee for helpful comments. The final version of this paper was improved by their input. Any remaining errors are solely our responsibility. This work was supported by JSPS KAKENHI Grant Number 16K03760.

\section{References}

[1] Leland, H. and Pyle, D. (1997) Information Asymmetries, Financial Structure and Financial Intermediation. Journal of Finance, 32, 371-387. https://doi.org/10.2307/2326770

[2] Sharpe, S.A. (1990) Asymmetric Information, Bank Lending, and Implicit Contracts: A Stylized Model of Customer Relationships. Journal of Finance, 45, 1069 1087.

[3] Rajan, R.G. (1992) Insiders and Outsiders: The Choice between Informed and Arm's-Length Debt. Journal of Finance, 47, 1367-1400. https://doi.org/10.1111/j.1540-6261.1992.tb04662.x

[4] Hannan, T. (1991) Bank Commercial Loan Markets and the Role of Market Structure: Evidence from Surveys of Commercial Lending. Journal of Banking and Finance, 15, 133-149. https://doi.org/10.1016/0378-4266(91)90042-K

[5] Black, S.E. and Strahan, P.E. (2002) Entrepreneurship and Bank Credit Availability. The Journal of Finance, 57, 2807-2833. https://doi.org/10.1111/1540-6261.00513

[6] Beck, T., Demirguc-Kunt, A. and Maksimovic, V. (2004) Bank Competition and Access to Finance: International Evidence. Journal of Money, Credit, and Banking, 36, 627-648. https://doi.org/10.1353/mcb.2004.0039

[7] Agostino, M. and Trivieri, F. (2010) Is Banking Competition Beneficial to SMEs? An Empirical Study Based on Italian Data. Small Business Economics, 35, 335-355. https://doi.org/10.1007/s11187-008-9154-6

[8] Chong, T.T.L., Lu, L. and Ongena, S. (2013) Does Banking Competition Alleviate Or Worsen Credit Constraints Faced by Small- and Medium-Sized Enterprises? Evidence from China. Journal of Banking and Finance, 37, 3412-3424. https://doi.org/10.1016/j.jbankfin.2013.05.006

[9] Petersen, M.A. and Rajan, R.G. (1994) The Benefits of Lending Relationships: Evidence from Small Business Data. Journal of Finance, 49, 3-37. https://doi.org/10.1111/j.1540-6261.1994.tb04418.x 
[10] Petersen, M.A. and Rajan, R.G. (1995) The Effect of Credit Market Competition on Firm-Creditor Relationships. Quarterly Journal of Economics, 110, 407-443. https://doi.org/10.2307/2118445

[11] Zarutskie, R. (2003) Does Bank Competition Affect How Much Firms Can Borrow? New Evidence from the US. In: Proceedings of a Conference on Bank Structure and Competition, Federal Reserve Bank of Chicago, Chicago, 121-136.

[12] Fischer, K.H. (2005) Acquisition of Information in Loan Markets and Bank Market Power: An Empirical Investigation. In: Proceedings of the 2005 Annual Conference on Bank Structure and Competition, Federal Reserve Bank of Chicago, Chicago, 4-6.

[13] Jayaratne, J. and Wolken, J.D. (1999) How Important Are Small Banks to Small Business Lending? New Evidence from a Survey to Small Businesses. Journal of Banking and Finance, 23, 427-458. https://doi.org/10.1016/S0378-4266(98)00085-5

[14] Berger, A.N., Demirguc-Kunt, A., Levine, R. and Haubrich, J.G. (2004) Bank Concentration and Competition: An Evolution in the Making. Journal of Money, Credit, and Banking, 36, 433-451. https://doi.org/10.1353/mcb.2004.0040

[15] Yamori, N. and Murakami, A. (1999) Does Bank Relationship Have an Economic Value? The Effect of Main Bank Failure on Client Firms. Economics Letters, 65, 115-120. https://doi.org/10.1016/S0165-1765(99)00133-0

[16] Dunne, T., Roberts, M.J. and Samuelson, L. (1988) Patterns of Firm Entry and Exit in U.S. Manufacturing Industries. Rand Journal of Economics, 19, 495-515. https://doi.org/10.2307/2555454

[17] Geroski, P.A. (1991) Domestic and Foreign Entry in the UK: 1983-84. In: Geroski, P. and Schwalbach, J., Eds., Entry and Market Contestability. An International Comparison, Blackwell Oxford, Oxford, 63-88.

[18] Cetorelli, N. and Strahan, P.E. (2006) Finance as a Barrier to Entry: Bank Competition and Industry Structure in Local U.S. Markets. The Journal of Finance, 61, $437-$ 461. https://doi.org/10.1111/j.1540-6261.2006.00841.x

[19] Rogers, T. (2012) Bank Market Structure and Entrepreneurship. Small Business Economics, 39, 909-920. https://doi.org/10.1007/s11187-011-9320-0

[20] Jayaratne, J. and Strahan, P. (1996) The Finance-Growth Nexus: Evidence from Bank Branch Deregulation. Quarterly Journal of Economics, 111, 639-670. https://doi.org/10.2307/2946668

[21] Kerr, W. and Nanda, R. (2009) Democratizing Entry: Banking Deregulations, Financing Constraints, and Entrepreneurship. Journal of Financial Economics, 94, 124-149. https://doi.org/10.1016/j.jfineco.2008.12.003

[22] Rice, T. and Strahan, P. (2010) Does Credit Competition Affect Small-Firm Finance? Journal of Finance, 65, 861-889. https://doi.org/10.1111/j.1540-6261.2010.01555.x

[23] Cetorelli, N. and Gambera, M. (2001) Banking Market Structure, Financial Dependence and Growth: International Evidence from Industry Data. The Journal of Finance, 56, 617-648. https://doi.org/10.1111/0022-1082.00339

[24] Boot, W. (2000) Relationship Banking: What Do We Know? Journal of Financial Intermediation, 9, 7-25. https://doi.org/10.1006/jfin.2000.0282

[25] Degryse, H. and Van Cayseele, P. (2000) Relationship Lending within a Bank-Based System: Evidence from European Small Business Data. Journal of Financial Intermediation, 9, 90-109. https://doi.org/10.1006/jfin.1999.0278

[26] Chakraborty, A. and Hu, C.X. (2006) Lending Relationships in Line-of-Credit and 
Non Line-of-Credit Loans: Evidence from Collateral Use in Small Business. Journal of Financial Intermediation, 15, 86-107. https://doi.org/10.1016/j.jfi.2005.07.002

[27] Berger, A.N. and Udell, G.F. (2002) Small Business Credit Availability and Relationship Lending: The Importance of Bank Organizational Structure. The Economic Journal, 112, 32-53. https://doi.org/10.1111/1468-0297.00682

[28] Scott, J.A. (2004) Small Business and the Value of Community Financial Institutions. Journal of Financial Services Research, 25, 207-230. https://doi.org/10.1023/B:FINA.0000020661.30763.fe

[29] Bonaccorsi Di Patti, E. and Dell'Ariccia, G. (2004) Bank Competition and Firm Creation. Journal of Money, Credit, and Banking, 36, 225-251. https://doi.org/10.1353/mcb.2004.0011

[30] Shimizu, K. (2012) Bankruptcies of Small Firms and Lending Relationship. Journal of Banking and Finance, 36, 857-870. https://doi.org/10.1016/j.jbankfin.2011.09.016

[31] Berger, A.N., Cerqueiro, G. and Penas, M.F. (2015) Market Size Structure and Small Business Lending: Are Crisis Times Different from Normal Times? Review of Finance, 19, 1965-1995. https://doi.org/10.1093/rof/rfu042

[32] Berger, A., Kayshap, A. and Scalise, J. (1995) The Transformation of the US Banking Industry: What a Long Strange Trip It's Been. Brookings Papers on Economic Activity, 2, 155-219.

[33] Berger, A.N. and Udell, G.F. (1996) Universal Banking and the Future of Small Business Lending. In: Saunders, A. and Walter, I., Eds., Financial System Design: The Case for Universal Banking, Irwin Publishing, Burr Ridge, 559-627.

[34] Keeton, W. (1995) Multi-Office Bank Lending to Small Businesses: Some New Evidence. Federal Reserve Bank of Kansas City Economic Review, 80, 45-57.

[35] Shapiro, D. and Khemani, R.S. (1987) The Determinants of Entry and Exit Reconsidered. International Journal of Industrial Organization, 5, 15-26. https://doi.org/10.1016/0167-7187(87)90003-8

[36] Dunne, T. and Roberts, M.J. (1991) Variation in Producer Turnover across US Manufacturing Industries. In: Geroski, P.A. and Schwalbach, J., Eds., Entry and Market Contestability: An International Comparison, Blackwell, London, 187-203.

[37] Evans, L.B. and Siegfried, J.J. (1992) Entry and Exit in United States Manufacturing Industries from 1977 to 1982. In: Audretsch, D.B. and Siegfried, J.J., Eds., Empirical Studies in Industrial Organization: Essays in Honor of Leonard W. Weiss, Kluwer Academic, Dordrecht, 253-273. https://doi.org/10.1007/978-94-011-2795-0_14

[38] Bernard, A.B. and Jensen, J.B. (2007) Firm Structure, Multinationals, and Manufacturing Plant Deaths. The Review of Economics and Statistics, 89, 193-204. https://doi.org/10.1162/rest.89.2.193

[39] Philips, B.D. and Kirchhoff, B.A. (1989) Formation, Growth, and Survival: Small Firm Dynamics in the U.S. Economy. Small Business Economics, 1, 65-74. https://doi.org/10.1007/BF00389917

[40] Anagnostaki, V. and Louri, H. (1995) Entry and Exit from Greek Manufacturing Industry: A Test of the Symmetry Hypothesis. International Review of Applied Economics, 9, 86-95. https://doi.org/10.1080/758534482

[41] Love, J.H. (1996) Entry and Exit: A County-Level Analysis. Applied Economics, 28, 441-451. https://doi.org/10.1080/000368496328579

[42] Fotopoulos, G. and Spence, N. (1998) Entry and Exit from Manufacturing Industries: Symmetry, Turbulence and Simultaneity-Some Evidence from Greek Manufacturing Industries 1982-1988. Applied Economics, 30, 245-262. 
https://doi.org/10.1080/000368498326047

[43] Austin, J.S. and Rosenbaum, D.I. (1990) The Determinants of Entry and Exit Rates into U.S. Manufacturing Industries. Review of Industrial Organization, 5, 211-223. https://doi.org/10.1007/BF02229762

[44] Carree, M. and Thurik, R. (1996) Entry and Exit in Retailing: Incentives, Barriers, Displacement and Replacement. Review of Industrial Organization, 11, 155-172. https://doi.org/10.1007/BF00157664

[45] Manjón-Antolín, M.C. (2010) Firm Size and Short-Term Dynamics in Aggregate Entry and Exit. International Journal of Industrial Organization, 28, 464-476. https://doi.org/10.1016/j.ijindorg.2009.11.002

[46] Guesnier, B. (1994) Regional Variation in New Firm Formation. Regional Studies, 28, 347-358. https://doi.org/10.1080/00343409412331348316

[47] Armington, C. and Acs, Z.J. (2002) The Determinants of Regional Variation in New Firm Formation. Regional Studies, 36, 33-45. https://doi.org/10.1080/00343400120099843

[48] Audretsch, D.B. and Fritsch, M. (1994) The Geography of Firm Births in Germany. Regional Studies, 28, 359-366. https://doi.org/10.1080/00343409412331348326

[49] Garofoli, G. (1994) New Firm Formation and Regional Development. Regional Studies, 28, 381-394. https://doi.org/10.1080/00343409412331348346

[50] Baltagi, B.H. (1981) Simultaneous Equations with Error Components. Journal of Econometrics, 17, 189-200. https://doi.org/10.1016/0304-4076(81)90026-9

[51] Balestra, P. and Varadharajan-Krishnakumar, J. (1987) Full Information Estimations of a System of Simultaneous Equations with Error Components Structure. Econometric Theory, 3, 223-246. https://doi.org/10.1017/S0266466600010318 